Pesq. Vet. Bras. 37(9):931-936, setembro 2017 DOI: $10.1590 / \mathrm{S} 0100-736 \mathrm{X} 2017000900006$

\title{
Geospatial distribution and risk factors for bovine cysticercosis in the state of Rondônia, Brazil ${ }^{1}$
}

\author{
Wellington C. Alves ${ }^{2}$, Gabriel A.M. Rossi ${ }^{3 *}$, Welber D.Z. Lopes ${ }^{4}$, Henrique M.S. \\ Almeida $^{2}$, Luis A. Mathias ${ }^{2}$, Ana Maria C. Vidal ${ }^{5}$ and Vando E. Soares ${ }^{6}$
}

\begin{abstract}
Alves W.C., Rossi G.A.M., Lopes W.D.Z., Almeida H.M.S., Mathias L.A., Vidal A.M.C. \& Soares V.E. 2017. Geospatial distribution and risk factors for bovine cysticercosis in the state of Rondônia, Brazil. Pesquisa Veterinária Brasileira 37(9):931-936. Faculdade de Ciências Agrárias e Veterinárias, Universidade Estadual Paulista Júlio de Mesquita Filho, Via de acesso Prof. Paulo Donato Castellane s/n, Jaboticabal, SP 14884-900, Brazil. E-mail: gabrielrossiveterinario@hotmail.com

This study focused on assessing the prevalence, geospatial distribution and risk factors for bovine cysticercosis in cattle from the state of Rondônia, Brazil, through the years 2012 to 2015. The prevalence established was $0.014 \%$ (95\% C.I. 0.013-0.014), with a higher detection of unviable cysticerci (84.80\%). The municipalities of Itapuã do Oeste, Candeias do Jamari, Nova Brasilândia D’Oeste, Pimenteiras do Oeste, Porto Velho, Nova Mamoré, Urupá and Guajará-Mirim had higher risk $(\mathrm{OR}>1 ; \mathrm{p}<0.05)$ for cysticercosis occurrence compared with the municipality of Castanheiras (OR=1). The Administrative Regions of Porto Velho, Guajará-Mirim, Colorado D'Oeste, Cacoal, Ji-Paraná had higher risk $(O R>1 ; p<0.05)$ for cysticercosis occurrence in the slaughtered animals than those reared in Ariquemes Administrative Region $(\mathrm{OR}=1)$. Some variables such as human population density $(\mathrm{OR}=2.15$; 2.15-2.16), percentage of urban houses with inappropriate sewage system (OR=1.91, 1.91.1.92) and percentage of inappropriate rural sewage system (OR=1.14, 1.14-1.14) were significantly associated $(\mathrm{p}<0.05)$ with the occurrence of bovine cysticercosis. In conclusion, the prevalence of bovine cysticercosis in the state of Rondônia was $0.014 \%$ (95\% C.I. 0.013-0.014) and higher-risk areas were identified, providing useful information to Official Sanitary Inspection System in order to improve cysticercosis detection. Also, human population density and the lack of appropriate sewage system in urban and rural areas are closely related to bovine cysticercosis occurrence in this state.
\end{abstract}

INDEX TERMS: Epidemiology, Geographic Information System (GIS), Taenia saginata, zoonoses.

\footnotetext{
${ }^{1}$ Received on November 11, 2016.

Accepted for publication on March 7, 2017.

${ }^{2}$ Fiscal Federal do Ministério da Agricultura, Pecuária e Abastecimento, Brazil.E-mail: carreta_alves@hotmail.com

${ }^{3}$ Departamento de Medicina Veterinária Preventiva e Reprodução Animal, Faculdade de Ciências Agrárias e Veterinárias (FCAV), Universidade Estadual Paulista (Unesp), Via de acesso Paulo Castellane s/n, Jaboticabal, SP 14884-900, Brazil. E-mails: Imathias@fcav.unesp.br, henri_almeida 2004@yahoo.com.br; *Corresponding author: gabrielrossiveterinario@ hotmail.com

${ }^{4}$ Instituto de Patologia Tropical e Saúde Pública, Universidade Federal de Goiás (UFG), Goiânia, GO 74605-050, Brazil. E-mail: wdzlopes@hotmail.com

${ }^{5}$ Faculdade de Zootecnia e Engenharia de Alimentos (FZEA), Universidade de São Paulo (USP), Av. Duque de Caxias Norte 225, Pirassununga, SP 13635-900, Brazil.E-mail: anavidal@usp.br

${ }^{6}$ Universidade Camilo Castelo Branco (Unicastelo), Av. Hilário da Silva Passo 950, Descalvado, SP 13690-970, Brazil. E-mail: soaresvando@gmail.com
}

RESUMO.- [Distribuição espacial e fatores de risco para a cisticercose bovina no Estado de Rondônia, Brasil.] Este estudo objetivou avaliar a prevalência, distribuição espacial e fatores de risco para a ocorrência de cisticercose bovina em animais abatidos oriundos do Estado de Rondônia, Brasil, entre os anos de 2012 a 2015. A prevalência observada foi de $0,014 \%$ (I.C. 95\% 0,013-0,014), com maior detecção de cisticercos inviáveis $(84,80 \%)$. Os municípios de Itapuã do Oeste, Candeias do Jamari, Nova Brasilândia D'Oeste, Pimenteiras do Oeste, Porto Velho, Nova Mamoré, Urupá e Guajará-Mirim apresentaram maior risco $(O R>1 ; p<0.05)$ para a ocorrência da enfermidade quando comparadas ao município de Castanheiras $(\mathrm{OR}=1)$. As Regiões Administrativas de Porto Velho, Guajará-Mirim, Colorado D’Oeste, Cacoal, Ji-Paraná, respecti- 
vamente, apresentaram maior risco $(O R>1 ; p<0.05)$ para a ocorrência de cisticercose nos bovinos abatidos comparadas à Região Administrativa de Ariquemes ( $\mathrm{OR}=1$ ). Algumas variáveis como a densidade populacional humana $(\mathrm{OR}=2,15 ; 2,15-2,16)$, percentual de domicílios urbanos com saneamento inadequado $(\mathrm{OR}=1,91,1,91-1,92)$ e percentual de saneamento rural inadequado $(\mathrm{OR}=1,14$, 1,14-1,14) apresentaram-se como fatores de risco significativos $(\mathrm{p}<0.05)$ para a ocorrência de cisticercose bovina. Conclui-se que a prevalência de cisticercose bovina no Estado de Rondônia foi 0,014\% (I.C. 95\% 0,013-0,014) e que áreas de maior ocorrência puderam ser identificadas, fornecendo informações a serem utilizadas pelo Serviço de Inspeção Federal para melhorar a detecção dos casos. Ainda, a densidade da população humana e a deficiência de sistemas de tratamento de esgotos urbanos e rurais estão intimamente relacionadas com a ocorrência da cisticercose bovina neste estado.

TERMOS DE INDEXAÇÃO: Epidemiologia, Sistemas de Informações Geográficas (SIG), Taenia saginata, zoonoses.

\section{INTRODUCTION}

The teniasis-cysticercosis complex is a disease caused by Taenia saginata, a parasite that has humans as definitive hosts and cattle as intermediate host. Even though the disease presents worldwide distribution, the highest prevalence rates are present in developing and underdeveloped countries (OIE 2008), such as Brazil (Dutra et al. 2012). Scientific studies in several different brazilian states such as Paraná (Guimarães-Peixoto et al. 2012), Espiríto Santo (Avelar et al. 2016), Mato Grosso (Rossi et al. 2016) and Bahia (Bavia et al. 2012), have been performed in order to improve the understanding regarding bovine cysticercosis epidemiology and perpetration in Brazil.

Among the identified risk factors, the most important were cattle herds' access to contaminated water sources, presence of fishing activities near grazing areas (Rossi et al. 2015); contaminated feed sources (Jenkins et al. 2013), organic production systems (Calvo-Artavia et al. 2013a), use of sewage sludge to irrigate pasture (Cabaret et al. 2002) and proximity to densely populated areas (Rossi et al. 2016).

Despite the disease's epidemiology is unraveled, more studies are necessary to identify new associated risk factors, to provide more substantial data for decision-making process in intervention procedures in order to reduce the disease's prevalence in endemic areas, and consequently reducing economic losses for beef production chain (Laranjo-González et al. 2016).

Regarding the economical losses for beef production chain, 29,708,550 kg of beef were condemned due to cysticercosis only in the state of Paraná, Brazil, through the years 2010 to 2015 (Guimarães-Peixoto et al. 2012). Also, economical losses on around $£ 4.0$ million are estimated annually in England (Gracey et al. 1999). Furthermore, the performance of Geographic Information System (GIS) analysis is recommended to evaluate interlinks in health, human population and environmental data, turning possi- ble to better understand diseases epidemiology and social-environmental risk factors (Fletcher-Lartey \& Caprarelli 2016). So, studies using GIS and statistical analyses are required to reduce economic losses due its occurrence.

Considering the facts mentioned above, this study aimed to establish the prevalence, spatial distribution and risk factors for bovine cysticercosis in the state of Rondônia through the years 2012 to 2015.

\section{MATERIALS AND METHODS}

A set of data regarding the slaughter of 8,451,453 bovines from all the 52 municipalities in the state of Rondônia, Brazil through the years 2012 to 2015 was obtained. The state of Rondônia (1130'20" South/6334'20") is located in Brazilian Northern Region and it is bordered by the states of Mato Grosso (east), Amazon (north), Acre (west) and Bolívia (south and west). Rondônia state has $237,765.376 \mathrm{~km}^{2}$ of area, a human population estimated on 1,787,279 human beings and a cattle population in around $13,397,970$ animals (IBGE 2016). The cattle production is considered mostly extensive, showing low production indexes, mean stocking of $1.5 \mathrm{AU} /$ ha and also a recent increase of pasture's areas (Taborda 2015).

All data were gathered from reports of carcasses rejection occurrence from Brazilian Federal Inspection Service (SIF). These reports contained the number of slaughtered animals and the number of animals infected with viable or unviable cysticerci. Also, data was analyzed according to Administrative Region in which municipalities were included. The studied area was divided into eight Administrative Regions: Alvorada D’Oeste, Ariquemes, Cacoal, Colorado do Oeste, Guajará Mirim, Ji-Paraná, Porto Velho and Vilhena (Fig.1).

The animals' slaughter was performed according to the standard production technology and sanitary inspection model adopted in Brazil. The routine examination regarding the detection of cysticerci is performed on inspection lines, including palpation and incisions in head, tongue, heart, diaphragm and esophagus (Brazil 1952).

The statistical analysis was performed using the software Epiinfo 7.1.5.2 (WHO 2015). The calculation of prevalence's and 95\% confidence interval $(95 \% \mathrm{CI})$ were performed by Wilson's Method (Thrusfield 2010). To establish the municipalities and Administrative Regions that had a higher risk for cysticercosis occurrence, those one with the lowest prevalence were used (and considered as $\mathrm{OR}=1$ ), and the others were compared with them using Z-test to verify significance $(p<0.05)$ (Thrusfield 2010).

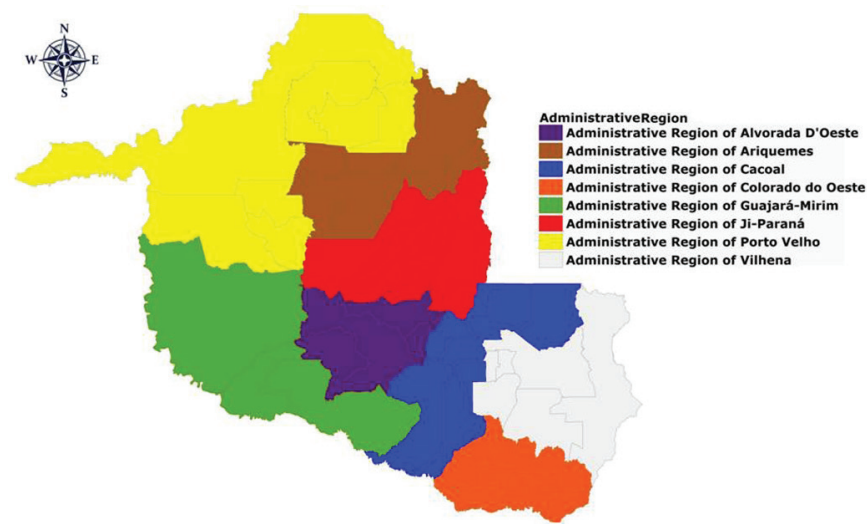

Fig.1. Geospatial distribution of the Administrative Regions which had cattle slaughtered in the state of Rondônia, Brazil, through the years 2012 to 2015 . 
Data regarding the banana production (ton), coffee production (ton), beans production (ton), yucca production (ton), percentage of houses with inappropriate sewage system, percentage of houses with open sewer, number of houses without bathroom, percentage of inadequate sewage system in rural area was obtained through the website of the Brazilian Institute of Geography and Statistics (IBGE 2015) for the same period than the cysticercosis occurrence data. Associations analyses between the prevalence (dichotomized by median value) with these variables were performed using linear regression analysis for each independent variable, considering $\mathrm{p}<0.2$ as significant.

A logistic regression analysis was performed later (adopting the variable total slaughtered animals as the weight variable), using the variables significant on the univariate analysis. The association strength was estimated by odds ratio (OR), obtained from logistic regression analysis and adopting significant $\mathrm{p}<0.05$. Maps using quantiles method (four categories) were created using the Terraview ${ }^{\circledR}$ Software.

\section{RESULTS}

In the period of 2012 to 2015 , there were 1,151 cases of cysticercosis among 8,451,453 slaughtered animals, resulting in a prevalence of $0.014 \%$ (95\% C.I. 0.013-0.014). When analyzing by each year separately, the prevalence values for 2012, 2013, 2014 and 2015 were respectively $0.024,0.011,0.009$ and 0.009 . Out of all detected cysticerci 175 (15.20\%) were viable, while 976 (84.80\%) were considered as unviable.

Regarding the occurrence by municipality, the prevalence varied from $0 \%$ in Castanheiras to $0.072 \%$ (95\% C.I. 0.050-0.094) in Guajará-Mirim. The spatial distribution of bovine cysticercosis prevalence in the municipalities is shown in Figure 2.

The cities of Itapuã do Oeste (OR=1.89; 1.01-3.52), Candeias do Jamari $(\mathrm{OR}=2.76 ; 2.04-3.75)$, Nova Brasilândia D'Oeste $(\mathrm{OR}=2.96 ; 2.04-4.31)$, Pimenteiras do Oeste $(\mathrm{OR}=3.55 ; 2.69-4.67)$, Porto Velho (OR=5.24; 4.58-5.99), Nova Mamoré (OR=4.73; 3.98-5.62), Urupá (OR=5.06; 3.227.97) and Guajará-Mirim (OR=5.44; 3.97-7.46) presented higher risk $(\mathrm{p}<0.05)$ to disease's occurrence when compared to the municipalty of Castanheiras (OR=1) (Fig.3).

Table 1 presents the results of prevalence and risk occurrence for bovine cysticercosis in eight Administrative Regions of the state of Rondônia. The Administrative Regions of Porto Velho, Guajará-Mirim, Colorado D’Oeste, Ca-

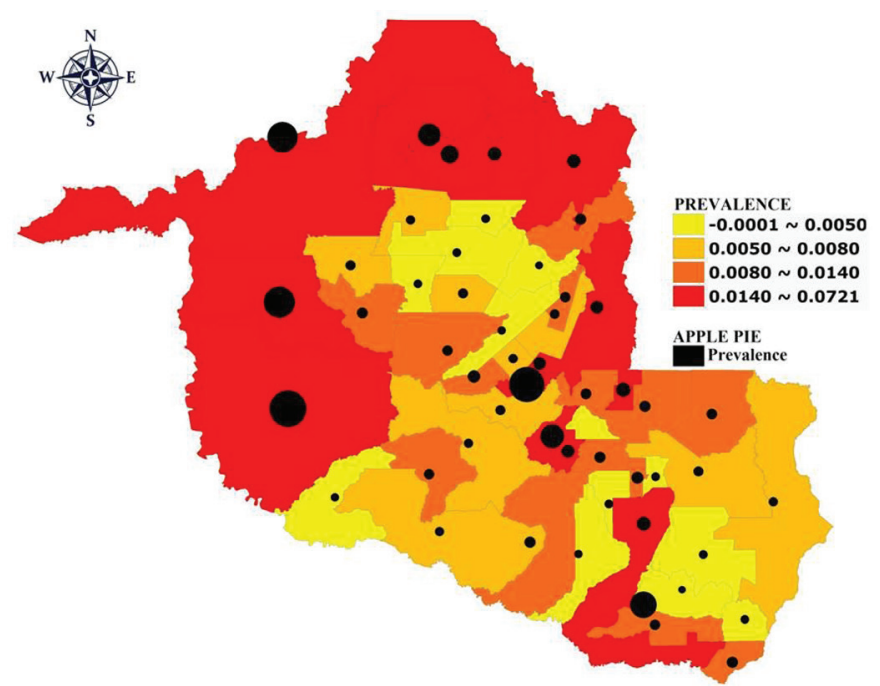

Fig.2. Geospatial distribution of bovine cysticercosis prevalence in the state of Rondônia, Brazil, through the years 2012 to 2015.

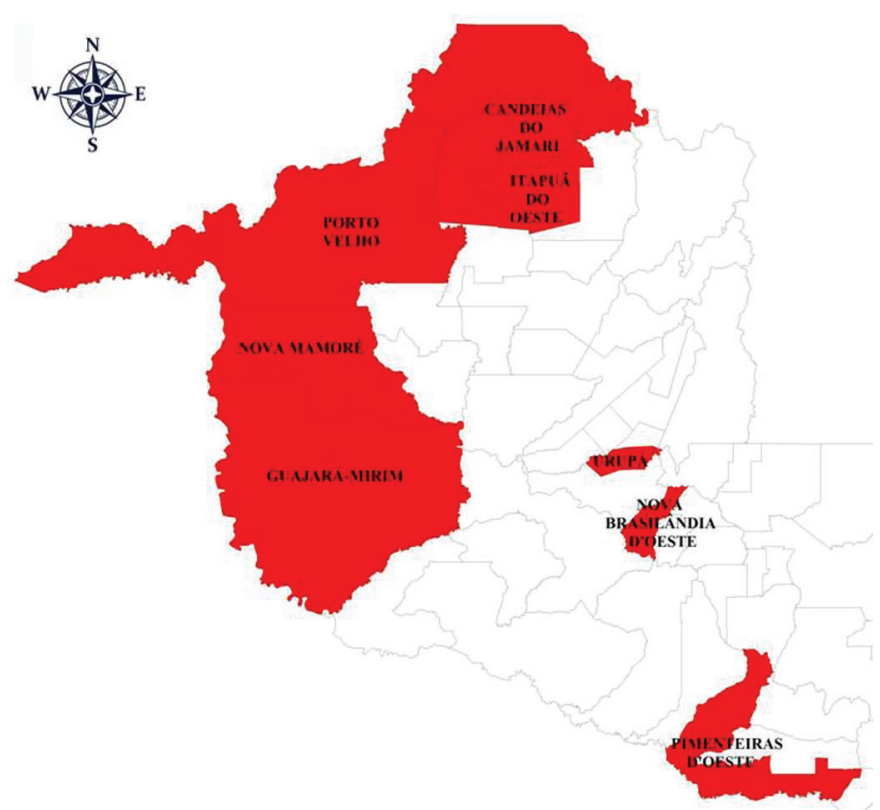

Fig.3. Municipalities located in the state of Rondônia, Brazil, that had significant risk $(0 R>1, \mathrm{p}<0.05)$ compared with Castanheiras (no detection) through the years 2012 to 2015.

Table 1. The total number of cattle slaughtered, number of cysticercosis negative and positive animals, cysticercosis prevalence, odds ratio (OR) and $95 \%$ Confidence Interval for cysticercosis occurrence and significance level in the eight Administrative Regions located in the state of Rondônia, Brazil, through the years 2012 to 2015

\begin{tabular}{|c|c|c|c|c|c|c|c|c|}
\hline \multirow{2}{*}{$\begin{array}{l}\text { Administrative } \\
\text { Regions }\end{array}$} & \multirow[t]{2}{*}{ Animals } & \multicolumn{2}{|c|}{ Cysticercosis } & \multirow[t]{2}{*}{ Prevalence } & \multicolumn{4}{|c|}{ OR } \\
\hline & & Negative & Positive & & Value & $95 \%$ CI & z statistic & Significance level \\
\hline Ariquemes & $1,050,018$ & $1,049,951$ & 67 & $0.006 \%$ & 1.00 & - & - & - \\
\hline Vilhena & $1,045,417$ & $1,045,347$ & 70 & $0.007 \%$ & 1.05 & 0.75 to 1.47 & 0.28 & 0.7780 \\
\hline Ji-Paraná & $1,627,477$ & $1,627,335$ & 142 & $0.009 \%$ & 1.37 & 1.02 to 1.83 & 2.11 & 0.0347 \\
\hline Cacoal & $1,591,893$ & $1,591,751$ & 142 & $0.009 \%$ & 1.40 & 1.05 to 1.87 & 2.26 & 0.0238 \\
\hline Alvorada D’Oeste & 464,766 & 464,713 & 53 & $0.011 \%$ & 1.79 & 1.25 to 2.56 & 3.16 & 0.0016 \\
\hline Colorado do Oeste & 666,306 & 666,229 & 77 & $0.012 \%$ & 1.81 & 1.31 to 2.51 & 3.56 & 0.0004 \\
\hline Guajará-Mirim & 523,313 & 523,251 & 62 & $0.012 \%$ & 1.86 & 1.31 to 2.62 & 3.51 & 0.0004 \\
\hline Porto Velho & $1,482,263$ & $1,481,725$ & 538 & $0.036 \%$ & 5.69 & 4.41 to 7.33 & 13.42 & $<0.0001$ \\
\hline Total & $8,451,453$ & $8,450,302$ & 1,151 & $0.0136 \%$ & & & & \\
\hline
\end{tabular}




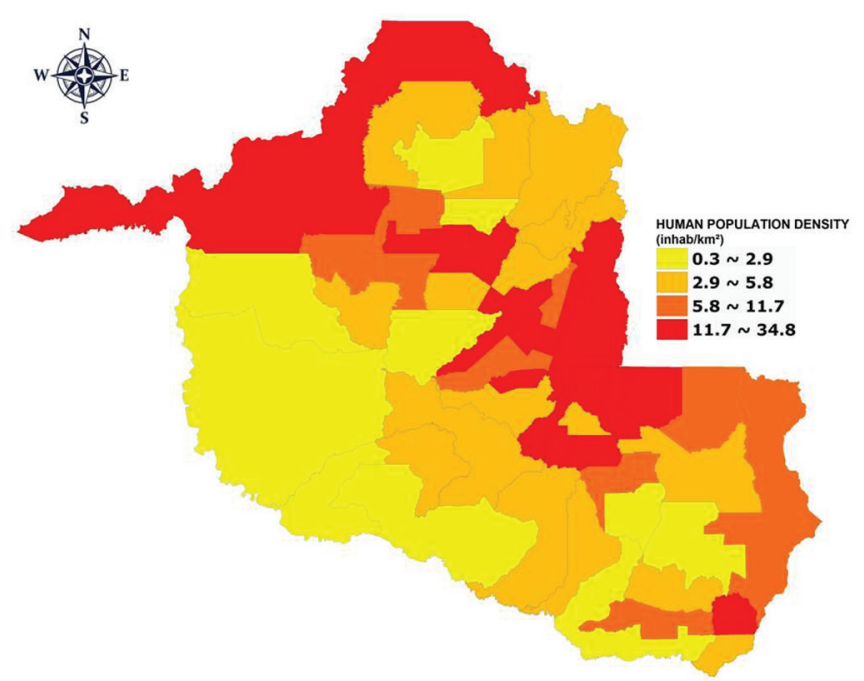

Fig.4. Geospatial distribution of the Human Population Density in the state of Rondônia, Brazil.

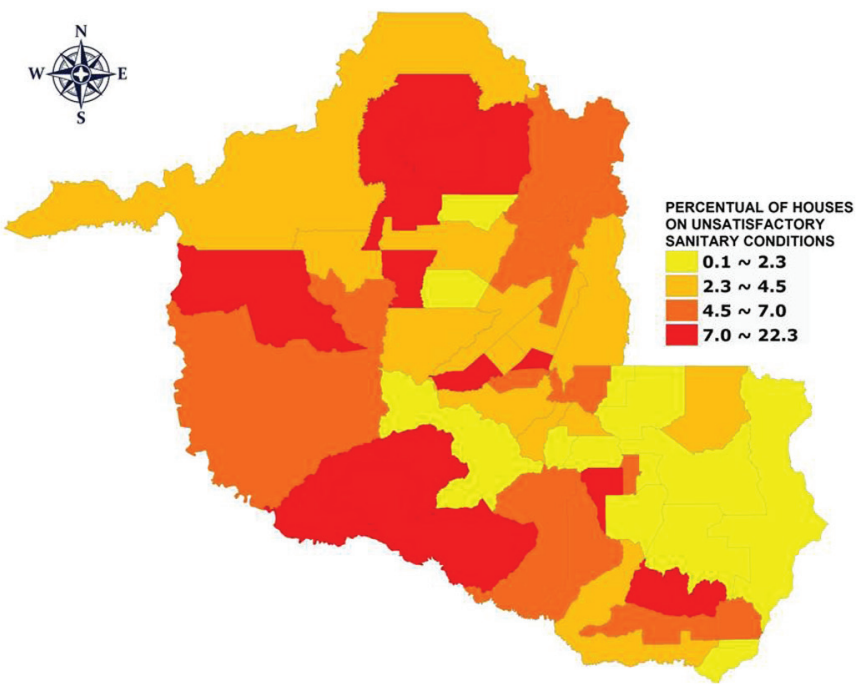

Fig.5. Geospatial distribution of the residences on unsatisfactory sanitation conditions in the state of Rondônia, Brazil.

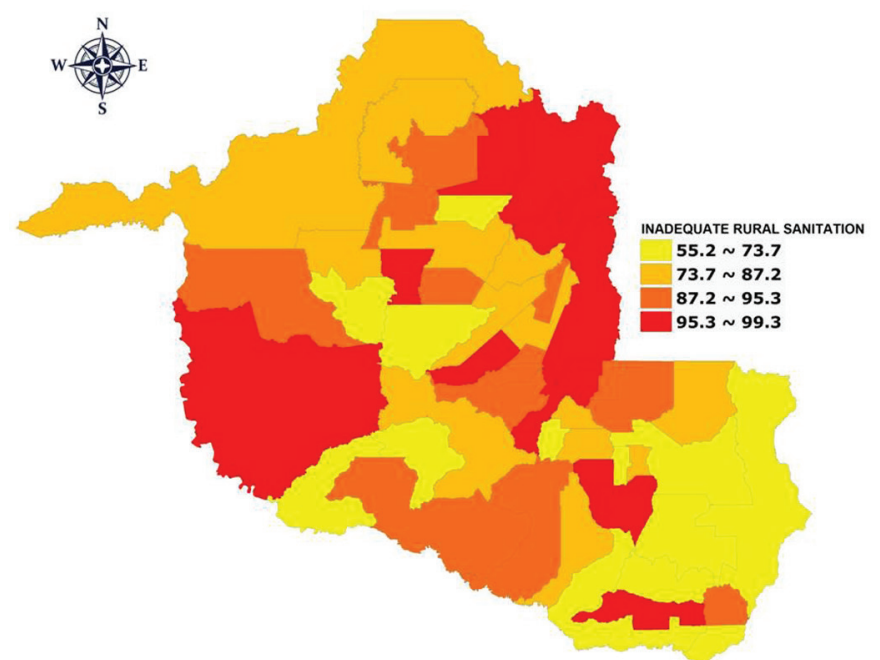

Fig.6. Geospatial distribution of the Inappropriate Rural Sanitation in the state of Rondônia, Brazil. coal, Ji-Paraná and Vilhena, had higher risk for cysticercosis occurrence when compared to the Administrative Region of Ariquemes, which presented the lowest prevalence $(\mathrm{OR}=1)$.

A logistic regression analysis was performed in order to assess the risk factors involved in the prevalence values found in the cities of the Rondonia state. The variables live cysticerci, calcified cysticerci, banana production (ton), coffee production (ton), beans production (ton), yucca production (ton), percentage of houses with inappropriate sewage system, percentage of houses with open sewer, number of houses without bathroom, percentage of inadequate sewage system in rural area and Administrative Regions were significant when assessed individually. Later, it was created a model in which the variables: human population density $(\mathrm{OR}=2.15 ; 2.15-2.16)$, percentage of urban houses with inappropriate sewage system $(\mathrm{OR}=1.91$; 1.91-1.92) and percentage of inadequate sewage system in rural areas $(\mathrm{OR}=1.14 ; 1.14-1.14)$ were significant $(\mathrm{p}<0.05)$ regarding bovine cysticercosis. The geospatial distribution of those variables in the municipalities is shown in Figure 4,5 , and 6 .

\section{DISCUSSION}

The prevalence established in the state of Rondônia (0.014\%) (95\% C.I. 0.013-0.014) is lower than other established in several other Brazilian states, such as São Paulo (2.92\%), Minas Gerais (1.81\%), Goiás (0.71\%), Mato Grosso do Sul (1.11\%) (Rossi et al 2015), Paraná (2.23\%) (Guimarães-Peixoto et al. 2012), Espiríto Santo (1.02\%) (Avelar et al. 2016) and Mato Grosso (0.0873\%) (Rossi et al. 2016). Other paper published regarding bovine cysticercosis prevalence in the same state, showed a prevalence of $0.07 \%(4,420 / 6,239,172)$ through the years 2007 to 2010 (Dutra et al. 2012), enforcing the theory that a reduction in the prevalence might be ongoing in this state.

The low prevalence value can be related to the low human population density observed in this state (6.58 inhab/ $\mathrm{km}^{2}$ ), compared to other states such as São Paulo, Espiríto Santo, Paraná, Minas Gerais and Goiás, where the respective population densities are 166.23, 76.25, 52.40, 33.41 and 17.65 inhab $/ \mathrm{km}^{2}$ (IBGE 2016). High human population density is considered as a risk factor for bovine cysticercosis occurrence in cattle herds in Brazil (Rossi et al. 2016).

The Brazilian law states that carcasses free of cysticerci or with only one, the affected muscled must be removed and the rest of the carcass may be sold. Carcasses with a single cistycerci are unsuitable to export. On the other hand, carcasses with intense cysticercosis, i.e. more than one cysticerci in an area of about $22 \mathrm{~cm}^{2}$, must be rendered. Finally, mild to moderate infections require freezing or canning (Brazil 1952), resulting in economical losses to beef production chain. Fukuda (2003) established economic losses of US\$23.27/infected due freezing treatment $\left(-10^{\circ} \mathrm{C}\right.$ for at least 10 days) of infected carcasses, the most commonly used method in Brazil. Hypothetically, considering 1,151 infected carcasses and that 30\% was treated by freezing (Rossi et al., 2015), it is possible to estimate economical losses of at least US\$ 8,035.00 due freezing of infected carcasses through the years of 2012 to 2015 in this state. 
The authors do not discharge the possibility of this prevalence be underestimated due the current sanitary inspection performed in bovine carcasses be unable to detect all infected animals because discreet infections or their occurrence on uncommon muscles such as shoulder blade, chuck, strip loin and full tenderloin, knuckle, back ribs and top round are reported (Lopes et al. 2011), consequently allowing human infections with taeniosis (González et al. 2015).

Using Geographic Information System (GIS) and statistical analyses, we identified the municipalities and Administrative Regions with high prevalence and the associated risk factors. However, one bias in our study is the cattle movement between properties and areas, a fact that could allow mistakes regarding the real local where infection occurred (Dupuy et al. 2015).

The municipality of Guajará-Mirim presented the highest risk for bovine cysticercosis occurrence $(\mathrm{OR}=5.44$; 3.97-7.46; $\mathrm{p}<0.005)$. This municipality is a common place for fishing and other water related leisure activities in the Mamoré-Guaporé valley and Pacaás river beaches, which are described as risk factors for bovine cysticiercosis occurrence (Flütsch et al. 2006, Rossi et al. 2015). In addition, the municipalities of Candeias do Jamari (OR=2.76; 2.04-3.75) and Itapuã do Oeste (OR=1.89; 1.01-3.52) also had higher risk, which could be related to the presence of Jamari river, the hydroelectric powerplant of Samuel and the fishing activity in the Guaporé river which can be involved in the higher occurrence in these areas (Rossi et al. 2015).

Moreover, the cities of Porto Velho, Nova Mamoré and Guajará-Mirim are in the route of the railway Madeira-Mamoré, a feature also pointed out as risk factor for cysticercosis occurrence (Flütsch et al. 2008).

Densely human populated areas (Fig.4) were associated as a risk factor for bovine cysticercosis, as previously described in the state of Mato Grosso, Brazil (Rossi et al. 2016), and pointed as potentially involved in the different prevalence established among Brazilian states (Rossi et al. 2015). Only one proglote of T. saginata can harbor up to 100,000 eggs resulting in a high environmental contamination (CDC 2016).

Nevertheless, the percentage of urban houses with inaproppriate sewage system $(\mathrm{OR}=1.91 ; 1.91-1.92)$ and inappropriate rural sewage system (OR=1.14; 1.14-1.14) (Fig.5 and 6) were significantly associated with the occurrence of bovine cysticercosis. Laranjo-González et al. (2016) highlight that the consumption of water contaminated with domestic sewage, the access to risky water with sewage treatment plant effluent in proximity, grazing next to streams and flooding on pastures were risk factors associated with cysticercosis occurrence, contributing to relations observed in this study. Furthermore, Kyvsgaard et al. (1991) established that to allow cattle accesses to drink water from streams carrying effluent from sewage treatment was considered as risk factor for cysticercosis occurrence due to water sources overflow containing T. saginata eggs and consequently widespread eggs on grassland and on other water sources (Cabaret et al. 2002).
Control measures such as the adoption of Good Agricultural Practices (GAP) by beef production farms and slaughterhouses (Rossi et al. 2015), sanitary education to prevent fecal contamination of the water, the proper destination and treatment of sewage effluents, establishment of rules for the agricultural use of sewage and sludge, health education, prevention of illegal slaughtering, basic sanitation and proper cooking of beef, providing education for farmers, pharmacological treatment (WHO 2002, Laranjo-González et al. 2016) and improvements in meat inspection to prevent human infections need to be adopted (Calvo-Artavia et al. 2013b, Rossi et al. 2016). Futhermore, other Brazilian states had its spatial distribution evaluated (Bavia et al. 2012, Guimarães-Peixoto et al., 2012, Avelar et al. 2016, Rossi et al. 2016) and these data should be useful for Brazilian Official Sanitary Inspection Service (SIF) to improve bovine cysticercosis detection in slaughterhouses.

\section{CONCLUSIONS}

The prevalence of bovine cysticercosis in the state of Rondônia was 0.014\% (95\% C.I. 0.013-0.014) and higher-risk areas were identified and this information should be used by the Official Sanitary Inspection System in order to improve cysticercosis detection.

Also, human population density and the lack of appropriate sewage system in urban and rural areas are closely related to bovine cysticercosis occurrence in this state

Conflict of interest statement.- The authors hereby declare that there is no conflict of interest in the study.

\section{REFERENCES}

Avelar B.R., Marcelino L.C., Campos R.F., Santos A.R. \& Martins I.V.F. 2016. Spatial analysis on the risk of bovine cysticercosis occurrence in the state of Espírito Santo, Brazil. Parasite Epidemiol. Control 1:116-123.

Bavia M.E., Carneiro D.D.M.T., Cardim L.L., Silva M.M.N. \& Martins M.S. 2012. Spatial Scan Statistic in the detection of risk areas for bovine cysticercosis in the state of Bahia. Arq. Bras. Med. Vet. Zootec. 64:1200-1208.

Brazil 1952. Regulation of industrial and sanitary inspection of animal products. Ministry of Agriculture, Livestock and Food Supply, Official Gazette, Brasilia, DF.

Cabaret J., Geerts S., Madeline M., Ballandonne C. \& Barbier D. 2002. The use of urban sewage sludge on pastures: the cysticercosis threat. Vet. Res. 33:575-597.

Calvo-Artavia F.F., Nielsen N.R., Dahl J., Clausen D.M. \& Alban L. 2013a. Occurrence and factors associated with bovine cysticercosis recorded in cattle at meat inspection in Denmark in 2004-2011. Prev. Vet. Med. 110:177-182.

Calvo-Artavia F.F., Nielsen N.R., Dahl J., Clausen D.M., Gaumann A.M. \& Alban L. 2013b. A case-control study of risk factors for bovine cysticercosis in Danish cattle herds. Zoonoses Public Health 60:311-8.

CDC 2016. Taeniasis. Centers for Disease Control and Prevention. <http:// www.cdc.gov/dpdx/taeniasis/> Accessed on 15. feb. 2016.

Dupuy C., Morlot C., Demont P., Callait-Cardinal M.P., Ducrot C., Calavas D. \& Gay E. 2015. Spatial analysis of bovine cysticercosis in France in 2010. Food Control 47:348-352.

Dutra L.H., Girotto A., Vieira R.F.C., Vieira T.S.W.J., Zangirolamo A.F., Marquês F.A.C., Headley S.A. \& Vidotto O. 2012. The prevalence and spatial epidemiology of cysticercosis in slaughtered cattle from Brazil. Semina, Ciênc. Agrárias 33:1887-1896.

Fletcher-Lartey S.M. \& Caprarelli G. 2016. Application of GIS technology in public health: successes and challenges. Parasitology 143:401-415. 
Flütsch F., Heinzmann D., Mathis A., Hertzberg H., Stephan R. \& Deplazes P. 2008. Case-control study to identify risk factors for bovine cysticercosis on farms in Switzerland. Parasitology 135:641-646.

Fukuda R.T. 2003. Contribuição ao estudo da epidemiologia da cisticercose bovina na região administrativa de Barretos. Aspectos ambientais e econômicos. PhD Thesis, Universidade Estadual Paulista, Jaboticabal, SP. 127p.

González S.A.C., Castillo J.L.R., Valencia G.L., Hurtado M.R.B., Robles E.S.H. \& Navarro F.J.M. 2015. Prevalence of Taenia saginata larvae (Cysticercus bovis) in feedlot cattle slaughtered in a Federal Inspection type abattoir in Northwest Mexico. Foodborne Pathog. Dis. 12:462-465.

Gracey J.F., Collins D.S. \& Huey R.J. 1999. Diseases caused by helminth and arthropod parasites, p.261-287. In: Ibid. (Eds), Meat Hygiene. 10th edn. W.B. Saunders, London.

Guimarães-Peixoto R.P.M., Souza V.K., Pinto P.S.A. \& Santos T.O. 2012. Distribuição e identificação das regiões de risco para a cisticercose bovina no Estado do Paraná. Pesq. Vet. Bras. 32:975-979.

IBGE 2015. Municipalities. Rondônia. Brazilian Institute of Geographic and Statistics. Available in <http://cidades.ibge.gov.br/xtras/ uf.php?lang=\&coduf=11\&search=rondonia $>$ Accessed on Sept. 21, 2016.

IBGE 2016. States. Brazilian Institute of Geographic and Statistics. Available in <http://www.ibge.gov.br/estadosat/index.php> Accessed on Sept. 21, 2016.

Jenkins D.J., Brown G.K. \& Traub R.J. 2013. “Cysticercosis storm” in feedlot cattle in North-West New South Wales. Aust. Vet. J. 91:89-93.

Kyvsgaard N.C., Ilsoe B., Willeberg P., Nansen P. \& Henriksen S.A. 1991. A case-control study of risk factors in light Taenia saginata cysticercosis in Danish cattle. Acta Vet. Scand. 32:243-252.

Laranjo-González M., Devleesschauwer B., Gabriel S., Dorny P. \& Allepuz, A. 2016. Epidemiology, impact and control of bovine cysticercosis in Europe: a systematic review. Parasit. Vectors 9:1-12.
Lopes W.D.Z., Santos T.R., Soares V.E., Nunes J.L.N., Mendonça R.P., Lima R.C.A., Sakamoto C.A.M., Costa G.H.N., Thomaz-Soccol V., Oliveira G.P. \& Costa A.J. 2011. Preferential infection sites of Cysticercus bovis in cattle experimentally infected with Taenia saginata eggs. Res. Vet. Sci. 90:8488.

Rossi G.A.M., Hoppe E.G.L., Mathias L.A., Martins A.M.C.V., Mussi L.A. \& Prata L.F. 2015. Bovine cysticercosis in slaughtered cattle as an indicator of Good Agricultural Practices (GAP) and epidemiological risk factors. Prev. Vet. Med. 118:504-508.

Rossi G.A.M., Simoni H.A.S., Lopes W.D.Z., Almeida H.M.S., Soares V.E., Vidal A.M.C. \& Mathias L.A. 2016. Prevalence and geospatial distribution of bovine cysticercosis in the state of Mato Grosso, Brazil. Prev. Vet. Med. 130:94-98.

Taborda J.M.M. 2015. Desenvolvimento da pecuária bovina no Estado de Rondônia: contextualização histórica e indicadores zootécnicos. MSc. Dissertation, Fundação Universidade Federal de Rondônia, Porto Velho, Rondônia. Available in <http://www.pgdra.unir.br/downloads/4658_jamile_macedo_dissertacao_2013_2015.pdf> Accessed on Oct. 2, 2016.

OIE 2008. OIE Terrrestrial Manual. Available in <http://web.oie.int/eng/ normes/MMANUAL/2008/pdf/2.09.05_CYSTICERCOSIS.pdf> Accessed on Sept. 30, 2016.

Thrusfield M.V. 2010. Veterinary Epidemiology. 3aㅡ ed. Rocca, São Paulo. $556 \mathrm{p}$.

WHO 2002. WHO, FAO, OIE Guidelines for the Surveillance, Prevention and Control of Taeniosis/Cysticercosis. Available at <http://www.oie. int/doc/ged/d11245.pdf> Accessed on Mar. 30, 2016.

WHO 2015. EPI INFO. Database and Statistics Software for Public Health Professionals. Centers for Disease Control and Prevention (CDC). Version 7.1.5.2, 2015. World Health Organization. 